Acta Poloniae Historica

107,2013

PL ISSN 0001-6892

Michat Tymowski

\title{
THE CULTURAL-PSYCHOLOGICAL ASPECTS OF THE PRESENCE OF AFRICAN SLAVES IN PORTUGAL IN THE FIFTEENTH AND EARLY SIXTEENTH CENTURIES*
}

Slavery in Portugal in the late Middle Ages and in modern times has been a subject of research in Portuguese historiography since the last decades of the nineteenth century. ${ }^{1}$ But the work of Charles Verlinden marked a significant turning point. His first volume, published in 1955, focuses on medieval slavery on the Iberian Peninsula and in France. Chapter VI is devoted to slavery in Portugal in the Age of Discovery. ${ }^{2}$ Verlinden examined the sources of slavery and the motives behind the Portuguese expeditions (such as the desire to Christianise the peoples of Africa and to make a profit); and he discussed the impact that these motives had on the phenomenon of slavery. He thoroughly analysed the profitability of the slave trade and he described the areas in which African slaves were employed in Portugal. Slaves most often worked as domestic servants, but they also worked as artisans, and occasionally in agriculture. Verlinden wrote about both black slaves and about white Moors, and he raised the issue of Jewish slaves.

Studies undertaken after the publication of Verlinden's research have been dominated by two types of interests, both of which emerged from this seminal work. They involve the economic and social significance of slavery. Vitorino Magalhães Godinho, Vicenta Cortez Alonso and

* This research, conducted in 2009-12, was financed from a grant by the Ministry of Science and Higher Education.

${ }^{1}$ Antonio P. de Carvalho, Das origens da escravidão moderna em Portugal (Lisbon, 1877); Pedro A. de Azevedo, 'Os Escravos', Archivo Historico Portugez, i (1903), 289-307; Manuel Heleno, Os escravos em Portugal (Lisbon, 1933); António Brásio, Os Pretos em Portugal (Lisbon, 1944); Edmundo A. C. Lopes, A escravatura (subsídios para a sua história) (Lisbon, 1944).

${ }^{2}$ Charles Verlinden, L'esclavage dans l'Europe médiévale, i: Péninsule Ibérique France (Bruges, 1955), 615-32. 
Virginia Rau analysed the economic aspects of slavery in the period of the early Portuguese expeditions to Africa. ${ }^{3}$ Marian Małowist and John L. Vogt researched the importance of the slave trade in the development of the island of São Tomé and the creation of sugar cane plantations there. ${ }^{4}$ Peter E. Russell took up social issues. ${ }^{5}$ The work of A. C. de C. M. Saunders is a synthesis of the social history of black slavery in Portugal from the fifteenth century to the mid-sixteenth century. ${ }^{6}$

Slavery and the presence of African slaves - black and white (Berbers and Arabs) - in Portugal in the fifteenth and sixteenth centuries had a significant impact on the history of the country, on many aspects of Portuguese social life, and on Portuguese customs and culture. Research in the fields of culture and literature has focused primarily on the image of black people in the Portuguese art of the late Middle Ages and modern times. Jean Devisse and Michel Mollat expanded the scope of this research to cover the whole of European art. ${ }^{7}$ Linguists and experts in literature conducted research on another topic, namely the simplified form of the Portuguese language used by slaves. This was the so-called fala de Guiné, fala dos pretos or fala dos negros - the speech of Guinea, or the speech of blacks. ${ }^{8}$

${ }^{3}$ Vitorino M. Godinho, A economia dos descobrimentos henriquinos (Lisbon, 1962). It is puzzling that, in his most famous work, L'économie de l'empire portugais aux XVe et XVIe siècles (Paris, 1969), Godinho did not deal with the slave trade. See also Vicenta C. Alonso, 'La trata de esclavos durante los primeros descubrimientos (14891516)', Anuario de estudios atlánticos, ix (1963), 23-46; Virginia Roberts Rau, 'Notes sur la traite portugaise à la fin du XVe siècle et le florentin Bartolomeo di Domenico Marchionni', Bulletin de l'Institut historique belge de Rome, 44 (1974), 535-43.

${ }^{4}$ Marian Malowist, 'Les débuts du système des plantations dans la période des grandes découvertes', Africana Bulletin, 10 (1969), 9-30; John L. Vogt, 'The Early Sao Tomé - Principe Slave Trade with Mina, 1500-1540', International Journal of African Historical Studies, vi, 3 (1973), 453-67.

${ }^{5}$ Peter E. Russell, 'Some Socio-Linguistic Problems Concerning the FifteenthCentury Portuguese Discoveries in the African Atlantic', in idem, Portugal, Spain and the African Atlantic, 1343-1490: Chivalry and Crusade from John of Gaunt to Henry the Navigator (Collected Studies Series, Cs496, Aldershot, 1995), text XIV, pp. 9-11 (1st edn, 1980); idem, 'Prince Henry and the Necessary End', in ibidem, text XVII, pp. 9-10 (1st edn, 1992).

${ }^{6}$ A. C. de C. M. Saunders, A Social History of Black Slaves and Freedmen in Portugal 1441-1555 (Cambridge and New York, 1982).

${ }^{7}$ Jean Devisse and Michel Mollat, L'Image du Noir dans l'art Occidental, ii: Des premiers siècles chrétiens aux grandes découvertes (Fribourg, 1979).

${ }^{8}$ Paul Teyssier, La langue de Gil Vicente (Paris, 1959). 
The study of black slavery in Europe was reinvigorated at the turn of the twentieth and twenty-first centuries. Of particular importance was the synthetic work of Alessandro Stella, which was devoted to slavery in the Iberian Peninsula from the sixteenth to nineteenth century, as well as a collection of articles edited by Tom F. Earle and Kathy J. Lowe, which focused on black slaves in Europe during the Renaissance. ${ }^{9}$ In both of these works, we can detect a shift in research interests from economic to cultural issues. In Stella's work, most of the material focuses on Spanish society. However, the collection of articles is dominated by description and analysis of slavery in Southern Europe, Spain, Italy, and southern Germany. Chapters devoted to Portugal cover slaves in the court of Lisbon, the brotherhood of Nossa Senhora do Rosario in Lisbon (and the social processes of slave adaptation), black slaves in the south of Portugal, and the literary work and life of the mulatto Afonso Alvares. A chapter devoted to European stereotypes of black slaves is particularly important for scholars approaching the topic from the perspective of cultural contact.

The purpose of my article is to analyse the psychological aspects of the African slave trade and the phenomenon of cultural contact that resulted from the presence of African slaves in Portugal. I have chosen a relatively short time period, from the early 1440s to the first years of the sixteenth century. The start date has been used in many works, and it seems obvious; after all, it was in 1441 that the first slaves captured in Africa were transported to Portugal. But the end date is debatable.

Verlinden finished his work on slavery at the end of the Middle Ages. However, many of the above-mentioned historians and experts in literature have studied the phenomenon of slavery and its consequences through to the end of the sixteenth century and well into the seventeenth century. The above-cited collection of articles on black slaves in Renaissance Europe covers the period from about 1440 to around 1600. In the study of slavery in various European countries, above all in Italy in the fifteenth century, use of the term Renaissance is, of course, appropriate. However, in the country of interest here, namely Portugal, the transition between medieval culture and

${ }^{9}$ Alessandro Stella, Histoire d'esclaves dans la péninsule Ibérique (Recherches d'histoire et de sciences sociales, 92, Paris, 2000); Thomas F. Earle and Kate J. P. Lowe (eds.), Black Africans in Renaissance Europe (Cambridge, 2005). 
the Renaissance came rather in the late fifteenth and early sixteenth century, which is significant because, in my opinion, ${ }^{10}$ this transition had a powerful impact on cultural contact between the Portuguese and the African slaves. This is the first reason why I distinguish the period from 1441 through the early sixteenth century.

Whereas Stella's work reaches into the nineteenth century and covers several eras, Saunders was interested in a shorter time span and adopted 1441-1555 as his time frame. He justified the latter date by citing the release in that year of the first publication in Portugal to criticize the cruelty of the slave trade and the treatment of slaves in Portugal. ${ }^{11}$ To be sure, this was the beginning of a long process of changing attitudes towards the issue of slavery but it seems doubtful to see in that date, and in that event, a threshold justifying the end of the research. In any case, in his work, Saunders often covers events that came two or three decades later.

By setting the beginning of the sixteenth century as the end date of my research I express my conviction that it was precisely at this in point in time that we begin to see major changes in Portuguese attitudes towards slavery, changes brought on by two phenomena. Firstly, the settlement of the previously uninhabited island of São Tomé. At the beginning of the sixteenth century, the Portuguese created a system of sugar-slave plantations there that would become the model for the organisation of plantations in Brazil and other parts of the New World. The mass export of slaves from Africa to America had already begun by the 1530s. The massive use of slave labour in plantation agriculture changed the attitudes towards slaves and their social function. From this perspective, the turning point of 1555 seems to be too late. The criticism of slavery was caused to a greater degree by the atrocities relating to the transatlantic trade, and to a lesser degree, by the situation of slaves in Portugal.

The second phenomenon that affected attitudes towards slavery relates to the peculiarities of the importation of African slaves to Portugal. The slave trade is of immense importance in the history

${ }^{10}$ Here I adopt the thesis put forward by Joaquim Barradas de Carvalho, À la recherche de la spécificité de la Renaissance portugaise, l'Esmeraldo de Situ Orbis de Duarte Pacheco Pereira et la littérature portugaise de voyages à l'époque des grandes découvertes: contribution à l'étude des origines de la pensée moderne, 2 vols. (Paris, 1983).

${ }^{11}$ Saunders, A Social History of Black Slaves, XI-XII. 
of Africa and there is an abundance of literature on this topic. With regard to West Africa, scholars have researched two different periods and types of slavery and human trafficking. From about the eighth century AD, trans-Saharan trade developed between Arab and Berber North Africa and the states of the Western Sudan, an important part of which was the slave trade. ${ }^{12}$ Most of these slaves were taken to Morocco, Egypt and the Middle East, though a certain number were sold to the Mediterranean countries of Christendom. In the sixteenth century, this trade began to decline in significance compared to a new development, namely the transatlantic slave trade. ${ }^{13}$ The importation to Portugal - in the fifteenth century and beginning of the sixteenth century - of slaves abducted or purchased in West Africa belongs neither to the first phenomenon (the trans-Saharan trade) nor to the second (the transatlantic trade). To be sure, Portuguese activities influenced both types of trade but the Portuguese slave trade of the fifteenth century was a separate phenomenon. Its size and role in the inter-regional and global economies were not large. Therefore, it can be treated as a prelude to the transatlantic trade. By choosing the beginning of the sixteenth century as a turning point, I wish to stress that the African slave trade in Portugal in the fifteenth and early sixteenth centuries was a phenomenon with peculiar features that are worth considering by themselves. And, beyond the economic and social aspects already explored, I wish to emphasise that the Portuguese slave trade between 1441 and the beginning of the sixteenth century had a distinct psychological and cultural aspect.

In a study of cultural contact between two separate groups of people, the numerical size of each group is of great importance. ${ }^{14}$

12 Edward W. Bovill, The Golden Trade of the Moors (Oxford, 1958); Marian Małowist, 'Le commerce de l'or et d'esclaves au Soudan Occidental', Africana Bulletin, 4 (1966), 49-72; Anthony G. Hopkins, An Economic History of West Africa (London, 1973); Ralph A. Austen, 'The Trans-Saharan Slave Trade: A Tentative Census', in Henry A. Gemery and Jan S. Hodendorn (eds.), The Uncommon Market: Essays in the Economic History of the Atlantic Slave Trade (New York, 1979).

${ }^{13}$ Gemery and Hodendorn (eds.), The Uncommon Market; Bronisław Nowak, 'Handel niewolnikami', in Michał Tymowski (ed.), Historia Afryki do początku XIX w. (Wrocław, 1996), 1168-1230, where also a very extensive literature on the topic is provided.

${ }^{14}$ Robert Redfield, Ralph Linton, and Melville J. Herskovits, 'Memorandum for the Study of Acculturation', American Anthropologist, N.S., xxxviii, 1 (1936), 149-52; 
We know that the population of Portugal in the middle of the sixteenth century was about 1 million. However, the number of slaves - forced new arrivals from Africa to Portugal - is something we can only estimate hypothetically. Statistical materials are in fact fragmentary and there was no continuous documentation. Moreover, numbers fluctuated between the year 1441 and the beginning of the sixteenth century; from small groups in the 1440s, the number of imported slaves grew to probably a few thousand a year at the end of the fifteenth century.

The chronicler Gomez Eanes de Zurara estimated that from the beginning of the expeditions through to the year 1448 (at which point he ended his work), 927 slaves had been transported from Africa. ${ }^{15}$ In subsequent years, the intensity of slave transports increased. On a single expedition in 1455, the Venetian Alvise Cadamosto purchased a hundred people in Africa. Cadamosto estimated the total number of slaves imported in the 1450s at between 800 and 1000 per year. ${ }^{16}$ In the 1480 s and 1490 s, the number of slaves imported into Portugal from Africa was much larger. The accounts kept by the administrator (almoxarife) of the Casa dos Escravos in Lisbon, Joham do Porto, indicate that, from 15 June 1486 to 31 December 1493, 3,589 slaves were transported from Guinea to Lisbon. In turn, the Florentine Bartolomeo Marchionni, who bought from the Crown the right to trade in Africa, imported - according to Verlinden's assessment 1,648 slaves in the years $1489-90$ and $1493-5 .{ }^{17}$ These numbers are fragmentary, though, they allow us to assume that in the last decades

Krzysztof Kwaśniewski, Zderzenie kultur. Tożsamość a aspekty konfliktów i tolerancji (Warsaw, 1982), 35-40.

${ }^{15}$ Gomes Eanes de Zurara, Crónica dos feitos notáveis que se passaram na conquista de Guiné por mandado do Infante D. Henrique (hereafter: Zurara/Soares), ed. Torquato de Sousa Soares, ii (Lisbon, 1981), 549. For an English translation, see The Chronicle of the Discovery and Conquest of Guinea written by Gomes Eanes de Azurara (hereafter: Zurara/Beazley), ed. and trans. Charles R. Beazley and Edgar Prestage, 2 vols. (New York, 1896); the translated quotes I provide from Zurara's chronicle come from this edition.

${ }^{16}$ Le navigazioni atlantiche del Veneziano Alvise Da Mosto (hereafter: Cadamosto/ Leporace), ed. Tullia Gasparrini Leporace (Il Nuovo Ramusio, 5, Rome, 1966), 27. See also Wilfrid Brulez, 'Les voyages de Cadamosto et le commerce guinéen au XVe siècle', Bulletin de l'Institut historique belge de Rome, 39 (1968), 311-26; for the number of slaves, see pp. 318-20.

17 Verlinden, L'esclavage, 625-7. 
of the fifteenth century, up to two thousand slaves were exported from Africa annually. However, the numbers fluctuated significantly, according to Saunders, from 300 to 2,000 slaves. ${ }^{18}$ Since not all slaves that were exported from Africa ended up in Portugal - some were exported to other kingdoms, mainly to Castile - the approximate number of black slaves in Portugal itself was around 10,000. A certain number of white slaves must also be added to this amount. In total, at the end of the fifteenth century and the beginning of the sixteenth century, slaves made up about one per cent of the population of Portugal. ${ }^{19}$

Saunders researched not only the number but also the distribution of slaves. In the study of cultural contact between the Portuguese and their African slaves, we must remember that the latter were concentrated in cities. There, the percentage of the slave population far exceeded the average for the whole country. Saunders calculates that, in the 1530s and 1540s, slaves comprised nearly 10 per cent of the population of Lisbon and the same was true of Évora. ${ }^{20}$ It is in these urban areas where the most intense contact took place.

Zurara described extensively the first large transport of African slaves into Lagos in 1444. Although this was not Lagos's first shipment of slaves, it made a great impression on the chronicler and local residents because of the number of slaves involved and because of the circumstances of their landing. Zurara's text provides an excellent example of the strong emotions the slave trade evoked. The passages of interest to us here have been quoted often, including by Verlinden, ${ }^{21}$ whose commentary - though brief - is absolutely on target. However, he did not develop the psychological thread of the analysis in the rest of his work perhaps because - in the 1950s - psycho-history was not yet an important part of historiography. Other researchers have analysed this section as a description of an exceptionally dramatic one-off event and not as the beginning of a process carried out through contact between Africans and the Portuguese. They have used it to call up the reader's empathy, not to have its words analysed. ${ }^{22}$

${ }^{18}$ Saunders, A Social History of Black Slaves, 19-27.

${ }^{19}$ Ibidem, 50-8.

${ }^{20}$ Ibidem, 51, 54-7.

${ }^{21}$ Verlinden, L'esclavage, $618 \mathrm{f}$.

22 Peter E. Russell, 'Prince Henry the Navigator', in idem, Portugal, text XI, pp. 25 f. (1st edn, 1960); Marian Małowist, Europa a Afryka Zachodnia $w$ dobie wczesnej ekspansji kolonialnej (Warsaw, 1969), 122-4. 
This passage, though already quoted in the literature, requires citing here, because no description can convey the particular tension expressed by Zurara. ${ }^{23}$ When caravels commanded by Lançarote returned from Africa and arrived at Lagos, the captains went ashore to report on the expedition. The next day, Lançarote told Prince Henry:

My Lord, your grace well knoweth that you have to receive the fifth of these Moors, and of all that we have gained in that land, whither you sent us for the service of God or of yourself. And now these Moors, because of the long time we have been at sea; as well as for the great sorrow that you must consider they have at heart, at seeing themselves away from the land of their birth, and placed in captivity, without having any understanding of what their end is to be; - and moreover because they have not been accustomed to a life on shipboard - for all these reasons are poorly and out of condition; wherefore it seemeth to me that would be well to order them to be taken out of the caravels at dawn ...

And so it happened.

Zurara began his description of the partition of the captives with a prayer:

O, THOU heavenly Father - who with Thy powerful hand, without alteration of Thy divine essence, governest all the infinite company of Thy Holy City ... I pray Thee that my tears may not wrong my conscience; for it is not their religion but their humanity that maketh mine to weep in pity for their sufferings. And if the brute animals, with their bestial feelings, by a natural instinct understand the sufferings of their own kind, what wouldst Thou have my human nature to do on seeing before my eyes that miserable company, and remembering that they too are of the generation of the sons of Adam. ${ }^{24}$

${ }^{23}$ For the entire description, see Zurara/Soares, 142-52; Zurara/Beazley, 79-85.

${ }^{24}$ Zurara/Beazley, 79-81; Zurara/Soares, 142-5: "Senhor: bem sabe a Vossa Mercê como haveis de haver o quinto destes mouros e de tudo o que ganhámos em aquela terra, onde por serviço de Deus e vosso nos mandastes. Mas, agora, estes mouros, pelo grande tempo que há que andámos no mar como também pelo nojo que deveis considerar que terão em seus corações, vendo-se fora da terra de sua naturalidade e postos em cativeiro sem haver qualquer conhecimento de qual será seu fim; depois, a usança que não hão de andar em navios; por tudo isto, vêm assaz mal dispostos e doentes. Pelo que me prece que será bom que, de manhã, os mandeis tirar das caravelas ... Ó Tu, Celestal Pai, que, com Tua poderosa mão sem movimento, de Tua divinal essência governas toda a infinida companhia da Tua santa cidade ... Eu Te rogo que as minhas lágrimas não sejam dano da minha 
Zurara's chronicle was hagiographic towards Henry the Navigator, but the scene of the partition of the human spoils must have shaken him deeply, since he mustered up the following words:

On the next day, which was the 8th of the month of August, very early in the morning, by reason of the heat, the seamen began to make ready their boats, and to take out those captives, and carry them on shore, as they were commanded. And these, placed all together in the field, were a marvellous sight; for amongst them were some white enough, fair to look upon, and well proportioned; others were less white like mulattoes; others again were as black as Ethiops, and so ugly, both in features and in body, and almost to appear (to those who saw them) the images of a lower hemisphere. But what heart could be so hard as not to be pierced with piteous feeling to see that company? For some kept their heads low and their faces bathed in tears, looking one upon another; others stood groaning very dolorously, looking up to the height of heaven, fixing their eyes upon it, crying out loudly, as if asking help of the Father of Nature; others struck their faces with the palms of their hands, throwing themselves at full length upon the ground; others made their lamentations in the manner of a dirge, after the custom of their country. And though we could not understand the words of their language, the sound of it right well accorded with the measure of their sadness. But to increase their sufferings still more, there now arrived those who had charge of the division of the captives, and who began to separate one from another, in order to make an equal partition of the fifths; and then was it needful to part fathers from sons, husbands from wives, brothers from brothers. No respect was shewn either to friends or relations, but each fell where his lot took him. ... And you who are so busy in making that division of the captives, look with pity upon so much misery; and see how they cling one to the other, so that you can hardly separate them. And who could finish that partition without very great toil? For as often as they had placed them in one part the sons, seeing their fathers in another, rose with great energy and rushed over to them; the mothers clasped their other children in their arms, and threw themselves flat on the ground with them; receiving blows with little pity for they own flesh, if only they might not be torn from them. And so troublously they finished the partition; for besides the toil they had with the captives, the field was quite full of people, both

consciência: porque, não por sua lei, destes, mas a sua humanidade constrange a minha [a] que chore piedosamente o seu padecimento. E se as brutas animálias com seu bestial sentir, por um natural instinto, conhecem os danos de seus semelhantes, que queres que faça esta minha humana naturaleza, vendo assim ante os meus olhos esta miserável companha, [e] lembrando-me que são da geração dos filhos de Adao?!" 
from the town (Lagos) and from the surrounding villages and districts, who for that day gave rest to their hands (in which lay their power to get their living) for the sole purpose of beholding this novelty. And with what they saw, while some were weeping and others separating the captives, they caused such a tumult as greatly to confuse those who directed the partition. The Infant was there, mounted upon a powerful steed, and accompanied by his retinue, making distribution of his favours, as a man who sought to gain but small treasure from his share; for of the forty-six souls that fell to him as his fifth, he made a very speedy partition of these. ${ }^{25}$

${ }^{25}$ Zurara/Beazley, 81-3; Zurara/Soares, 146-8: "No outro dia, que eram 8 dias do mês de Agosto, muito cedo pela manhã, por razão da calma, começaram os mareantes de aparelhar seus batéis e [de] tirar aqueles cativos para os levarem, segundo thes fora mandado. Os quais postos juntamente naquele campo, era uma maravilhosa coisa de ver: porque entre eles havia alguns de razoada brancura, formosos e apostos; outros, menos brancos, que queriam semelhar pardos; outros tão negros como Etiópios, tão desafeiçoados assim nas caras como nos corpos que quase parecia aos homens que os esguardavam que viam as imagens do hemisfério mais baixo. Mas qual seria o coração, por duro que ser pudesse, que não fosse pungido de piedoso sentimento vendo assim aquela companha? Porque uns tinham as caras baixas e os rostos lavados com lágrimas, olhando uns contra os outros; outros estavam gemendo mui dolorosamente, esguardando a altura dos céus, firmando os olhos em eles, bradando altamente como se pedissem socorro ao Pai da Natureza; outros feriam seu rosto com suas palmas, lançando-se estendidos em meio do chão; outros faziam suas lamentações em maneira de canto, segundo o costume de sua terra, aos quais (posto que as palavras da linguagem aos nossos nao pudesse ser entendida) bem correspondiam ao grau de sua tristeza. Mas para seu dó ser mais acrescentado, sobrevieram aqueles que tinham cargo da partilha, e começaram de os apartar uns dos outros a fim de porem seus quinhões em igualdade. Pelo que convinha de necessidade se apartarem os filhos dos pais; e as mulheres, dos maridos; e os irmãos, uns dos outros. A amigos nem a parentes, não se guardava nenhuma lei; sòmente, cada um caia onde a sorte o levava ... E vós outros, que vos trabalhais de [fazer] esta partilha: esguardai com piedade sobre tanta miséria, e vêde como se apertam uns aos outros que mal os podeis desligar. Quem poderia acabar aquela partição sem mui grande trabalho? Pois, logo que os tinham posto numa parte, os filhos que viam os pais na outra levantavam-se restamente e iam-se para eles; as mães apertavam os outros filhos nos braços e lançavam-se com eles de bruços, recebendo feridas, com pouca piedade de suas carnes, para lhes nao serem tirados. E assim trabalhosamente os acabaram de partir; porque, além do trabalho que tinham com os cativos, o campo era todo cheio de gente, assim do lugar como das aldeias e comarcas derredor, os quais deixavam em aquele dia folgar suas mãos em que restava a força do seu ganho, sòmente por ver aquela novidade. E com estas coisas que viam, uns chorando, outros falando, faziam tamanho alvoroço que punham em torvação os governadores daquela partilha. O Infante era ali, em cima de um poderoso cavalo, 
The chronicler drew some comfort from the notion that salvation of the slaves' souls was more important than their suffering: "for, as we said before, as soon as they understood our language they turned Christians with very little ado." And he added:

But from this time forth they began to acquire some knowledge of our country; in which they found great abundance, and our men began to treat them with great favour. For as our people did not find them hardened in the belief of the other Moors; and saw how they came in unto the law of Christ with a good will; they made no difference between them and their free servants, born in our own country. ${ }^{26}$

Slaves were baptised and their souls were saved, which justified, in Zurara's eyes, the conduct of Henry the Navigator and those around him. But the sight of emaciated prisoners and the enormity of their misfortune, especially when families were separated, caused ordinary people watching the event to protest. It led to tumult. Even the perpetrators 'feel confused'. Infante Henry managed to restore order and carry out the planned partition. In this scene, the human desperation felt by the slaves collided with the human compassion of the ordinary residents of Lagos; it collided with human greed and with the cruelty shown by the Infante milieu. Beyond that - even though the importation of African slaves had just begun - there emerged a certain ease by which other people's sufferings and one's own ruthless deeds could be justified by calling upon a higher good. Horrified ordinary people, who derived no benefit from the practice, expressed their sympathy. Similar feelings ran so deep within Zurara that he had to express them as well.

Zurara was probably a witness to this scene. He described not only the explosion of emotions but also the physical appearance of the

acompanhado de suas gentes, repartindo suas mercês como homem que de sua parte queria fazer pequeno tesouro. Porque de 46 almas que aconteceram no seu quinto, mui breve fez deles sua partilha ..."

${ }^{26}$ Zurara/Beazley, 84; Zurara/Soares, 148-9: “... pois ... como já dissemos, logo que haviam conhecimento da linguagem, com pequeno movimento se tornavam cristãos"; "[posto isso] foram eles porém ao diante havendo conhecimento da terra, na qual achavam grande abastança, e além disso [conhecimento de] como os tratavam com grande favor. Pois, porque as gentes os não achavam endurentados na crença dos outros mouros e viam que, de boa vontade, vinham para a lei de Cristo, não faziam de eles diferença [em ralação] aos servidores livres naturais da própria terra ..." 
captured Africans. Above all, he viewed them as humans, 'descendants of Adam'. And he saw more: their diverse features tied to race, appearance, sex and age. He saw - according to his own criteria beauty and ugliness. Most of these criteria would, in the future, be used in assessing the value of slaves. But in the moment when this scene was playing itself out, it was an experience that revealed to observers the diversity of the human race. Black slaves had been known in the Mediterranean world from antiquity and throughout the entire Middle Ages, ${ }^{27}$ but in this case, the vision of a group of about 230-40 humans allowed for more conclusions to be drawn; it was a new experience.

There is another passage in this section from Zurara's chronicle that requires mention, namely Lançarote's comments on the poor mental and physical health of the slaves resulting from their capture, the sudden change in their circumstances, the arduous sea voyage, their fears and despair. It is the only text from the fifteenth century that testifies to the conditions of transported slaves and that talks of the despair of the captured people.

In an article on fifteenth-century eyewitness accounts of the early discoveries, Peter Russell pointed out that Alvise Cadamosto, Antoniotto Usodimare and Eustache Delafosse did not write a word about the transportation of slaves to Portugal, ${ }^{28}$ even though each of them purchased slaves in Africa and wrote about these purchases without inhibition. From the moment when the human goods are loaded onto the caravels, they disappear from the descriptions. The only reference was left by Delafosse, who wrote about a female slave who had jumped into the sea to swim home to the Sierra Leone shore, and who was caught by a sloop sent in pursuit. ${ }^{29}$

Regarding the silence of travellers and merchants towards the conditions involved in the transport of slaves, the fact is that it was

${ }^{27}$ Frank M. Snowden, Blacks in Antiquity: Ethiopians in the Greco-Roman Experience (Cambridge, Mass., 1970); Iza Bieżuńska-Małowist and Marian Małowist, Niewolnictwo (Wielkie problemy dziejów człowieka, Warsaw, 1987), 46, 55-7, 320-4.

${ }^{28}$ Peter E. Russell, 'Veni, vidi, vici: Some Fifteenth-Century Eyewitness Accounts of Travel in the African Atlantic before 1492', in Joan-Pau Rubiés (ed.), Medieval Ethnographies: European Perceptions of the World Beyond (Aldershot, 2009), 315-28; on the lack of information, see p. 323 (the 1st edn of this article, 1993).

${ }^{29}$ Voyage d'Eustache Delafosse sur la côte de Guinée, au Portugal et en Espagne (1479-1481) (hereafter: Delafosse/Escudier), ed. Denis Escudier (Paris, 1992), 39. 
probably a very touchy subject; they had no desire to share their knowledge with readers. We must keep in mind that the caravels were small-sized vessels, and their crews consisted of 20-30 people. ${ }^{30}$ If between 30 and 50 slaves were crowded into a small caravel - and, according to Saunders, up to 120 slaves could fit into a large caravel, and 150 into a nau - conditions during transportation must have been dreadful. Some of the slaves died before they reached Portugal.

Zurara was comforted not only by the fact that the souls of baptised slaves had been saved. He also believed their lives in Portugal were better than in Africa. He recalled - as quoted - the good treatment they received, similar to the treatment received by free domestic servants. Not only were their souls saved but also their bodies. Because previously

they lived like beasts, without any custom of reasonable beings - for they had no knowledge of bread or wine, and they were without the covering of clothes, or the lodgment of houses; and worse than all, through the great ignorance that was in them, in that they had no understanding of good, but only knew how to live in a bestial sloth. But as soon as they began to come to this land, and men gave them prepared food and coverings for their bodies, their bellies began to swell, and for a time they were ill; until they were accustomed to the nature of the country; but some of them were so made that they were not able to endure it and died, but as Christians.

The blessing of being and living in captivity was therefore relative, even in Zurara's opinion. However, he persisted in convincing himself and his readers that this was all for the good of the Africans. He judged that the 'Moors' captured in West Africa differed greatly from those taken in North Africa:

First, that after they had come to this land of Portugal, they never more tried to fly, but rather in time forgot all about their own country, as soon as they began to taste the good things of this one; secondly, that they were very loyal and obedient servants, without malice; thirdly, that they were not so inclined to lechery as the others; fourthly, that after they began to use clothing they were for the most part very fond of display, so that they took great delight in robes of showy colours. ... And what is still better, as I have

30 Pierre Chaunu, L'expansion européenne du XIIIe au XVe siècle (Nouvelle Clio, 26, Paris 1969), 284-8; Saunders, A Social History of Black Slaves, 11. 
already said, they turned themselves with a good will into the path of the true faith ... and in this same they died. ${ }^{31}$

The text cited above can also be regarded as a kind of program for handling slaves. It was - using modern terminology - a program of acculturation. Zurara was not expressing his own views in this regard, but rather the views of his milieu - that is, the royal court and that of Infante Henry. No doubt, within the Infante's court, the most important goal was to baptise pagans, though it was not the only goal. They drew a sense of their own culture's superiority precisely from the fact that they were Christians. The inferiority and savagery - they attributed to Africans - were perceived as a consequence of their paganism. The end result of this reasoning was the possibility that, through baptism, these people could join the Christian community. As slaves, they would find themselves at the bottom of the social structure, but they would be members.

We can verify Zurara's opinion about the fate of African slaves from other parts of his chronicle, but above all, thanks to analysis of other sources. The slaves' feelings of unhappiness and their desire to gain freedom are evidenced by their attempts to escape. The earliest such example involves the fate of a slave named Adahu, a Berber captured in 1441 by an expedition led by Nuno Tristão. Adahu was the descendent of a noble family. The information he gave the Portuguese during questioning was regarded as valuable. He was lavished

${ }^{31}$ Zurara/Beazley, 84 f.; Zurara/Soares, 150-2: “... por viverem, assim, como bestas, sem qualquer preceito de criaturas racionais. Porque eles não sabiam que era pão nem vinho, nem cobertura de pano, nem alojamento de casa; e o pior, era a grande ignorância que em eles havia, pela qual não haviam qualquer conhecimento de bem; sòmente [sabiam] viver em uma ociosidade bestial. E logo, como començavam de vir a esta terra e lhes davam os mantimentos artificiais e as coberturas para os corpos, começavam de lhes crescer os ventres e, por tempos, eram enfermos até que se reformavam com a natureza da terra; em o que alguns deles eram tão compleicionados que o não podiam suportar, e morriaram, todavia cristãos ... a primeira, que depois que eram em esta terra nunca mais se trabalhavam de fugir, antes, com o tempo se esqueciam, de todo, da sua [terra], logo que começavam [a] sentir as bondades de esta; e a segunda, que eram muito leais e obedientes servidores sem malicia; e a terceira, que não eram tão chegados à luxúria como os outros; e a quarta, que depois que usavam os vestidos eram geralmente muito louçãos de vontade, pelo que folgavam muito com roupas de cores divisadas ... E o melhor era, como já tenho dito, que se tornavam de boa vontade ao caminho da Fé, na qual ... faziam seus finis." 
with gifts, but despite this affluence, he wanted his freedom back. Zurara referred to this with understanding, writing: "As you know that naturally every prisoner desireth to be free." Adahu asked the navigator Antão Gonçalves to take him back home, offering him five or six slaves in return. Two other captives also taken in 1441 promised two slaves each in return for their freedom. Thus, ten people could be taken for three. Henry the Navigator was convinced that it was better to save ten souls than three. In 1443, the caravels arrived near the coast (at the Rio de Ouro) where Adahu had been captured. He was to serve as an interpreter and to make contact with the Berbers in the area. They managed to start trading, but Adahu, who had been sent ashore, did not return to the caravel: "... the Moorish noble never returned to fulfil his promise neither did he remember the benefits he had received." 32 During another expedition in 1443 to Cape Blanco and the island of Arguin, another translator escaped - a slave serving on Gonçalo da Sintra's caravel. ${ }^{33}$ Apparently, the 'benefits' did not adequately compensate the slaves for their loss of freedom.

In the mid-1450s, when Cadamosto was travelling to Africa, translators no longer escaped. Perhaps controls had been tightened. Perhaps African rulers - such as Budomel who was trading with the Venetian - also required interpreters so they prevented them from escaping. ${ }^{34}$ It is also possible that over the years, as slaves got used to life in Portugal, the desire for freedom and to return home weakened. The situation for the translator-slaves was exceptional. Most of them were brought by caravel to those parts of the African coast where they had come from, which increased the chances of a successful escape. Other slaves taken to Portugal had almost no chance to get back to Africa, unless they served as caravel crew members, though a slave - who will be discussed shortly - named Pero Negro managed to escape with a few others on barges to Fez. If slaves escaped from their owners, they usually hid in Portugal or Castile. Of the more than 150 documents relating to slaves published in the Portugaliae

${ }^{32}$ Zurara/Beazley, 54, 57; Zurara/Soares, 103, 107. "Como sabeis, naturalmente todo preso deseja ser livre ... [o mouro cavaleiro] nunca tornou a satisfazer a sua menagem, nem tao pouco se lembrou do beneficio."

33 Zurara/Soares, 157.

${ }^{34}$ Cadamosto/Leporace, 49 f.; Michał Tymowski, 'How did European Explorers Communicate with Indigenous African People in the 15th Century?', Africana Bulletin, 50 (2002), 43-74; on the prevention of escape, see p. 54. 
Monumenta Africana (PMA), only 10 refer to fugitive slaves. ${ }^{35}$ Thus, escape was either a sporadic event, or - more likely - the runaway was found so quickly that it was not necessary to set a legal procedure in motion.

Escapes appear relatively late in the documents. The first mention, from 1488, relates to a complex situation. It involves an act of amnesty extended by King John II to João de Castanheira, a resident of Madeira who had facilitated the escape of João Penteado, a slave owned by Fernão Penteado, who had been condemned to exile on the island of São Tomé. No less complicated was the situation described in a document dated for 12 May 1493. It was the order for the manumission of a black slave, Pero Negro, from Cabo da Guiné, who had fled first to $\mathrm{Fez}$, but then returned to the Kingdom of Portugal because he felt himself to be a Christian and did not want lose his faith ("que vemdo elle que era cristao e nom queria leixar a fee de Nostro Senhor Jesuu Cristo se tornara a estes nosos regnnos."). ${ }^{36}$ Other documents providing evidence of escapes come from 1495 (two), 1496, 1497, 1500 (two), 1501 and 1502. Except for one, they are authorisations issued by owners to their representatives to find and return to the owner a fugitive slave. Perhaps, they were people sent in pursuit of the fugitives. Most of these documents come from the notarial records in Seville. They show the strong connections between Seville and Portugal. Two runaways (in records from 1495 and 1500) fled to Portugal, where they were pursued. About two other escapees (from the years 1496 and 1500) it is written that they spoke Portuguese. One of them, a slave named Anton, escaped in 1496 not to Portugal, but to Córdoba.

These records always include the names of slaves, their sex, their colour and their age. Ages range between 28 and 35 years; amongst the runaways, no one is particularly young or old and there is not a single woman. According to the records, some runaways "speak Portuguese". In two documents, a slave owner empowered his plenipotentiary not just to return the captured runaway but to sell him

${ }^{35}$ Portugaliae Monumenta Africana (hereafter: PMA), vols. 1-3, 5, ed. Luis de Albuquerque and Maria E. Madeira Santos (Lisbon, 1993-5), documents: 1/212 from 1488; 2/58 - 1493, 107 - 1495, 114 -1495, 153 - 1496, 164 - 1497; 3/24 - 1500, 50 - 1500, 90 - 1501, 130 - 1502.

${ }^{36}$ PMA, 2/58; the receiver of the king's order was Doctor Rui Boto, dean of the University of Coimbra, the owner of the slave. 
(1497 and 1502). Apparently, the owner anticipated further escapes and trouble.

These documents are from the 1490s and the beginning of the 1500s. They help us to establish that the vast majority of escapes ended quickly and were not recorded. However, another explanation is also possible, namely that the Portuguese documents were lost in an earthquake that shook Lisbon in the eighteenth century. A lack of documentation prior to 1488 , and its appearance in the 1490s, might be evidence of a change in the runaways' situation. Between 1440 and 1480, when there were relatively few slaves, their capture was easy and accomplished quickly. But once the number of black slaves greatly increased and once black freedmen began to appear (free people of African origin), the runaway's chances of escaping, hiding, and creating an appearance of legal residency in a given place became greater. The routines of slave life, which retained a certain latitude, could also favour escapees. There are many indications that the slave's daily routine resembled the life of free domestic servants and generally resembled the life led by free people in the lower social strata. This latitude in the life of a slave challenged the authorities to take countermeasures.

On 22 March 1502, a decree was issued in the name of King Manuel the Fortunate prohibiting slaves - male and female, black and white - from eating and drinking in taverns and shops and other places of this kind, public and private, both in Lisbon and in the surrounding area. Owners of inns and shops who broke the rules were subject to fines and taverns were ordered to close at night. ${ }^{37}$

The vast majority of documents concerning slaves published in the PMA involve the act of sale. These sales were performed using a formulary, on which it was recorded who was selling the slave, to whom, and for how much; then it gave the slave's name, sex, colour, age, place of origin in Africa (or birth in Europe). A similar formulary was used in bulk lists of slaves sold in specific months or years. If the shipment involved slaves who had just arrived from Africa, and were not yet baptised, then their names were not given; the only information recorded was the location where the ship had loaded the slaves and the number of slaves. This data - along with narrative texts - make up the primary source material for the study of the

37 PMA, 3/146. 
cultural contact and the psychological implications of the importation of slaves into Portugal during this period.

The overwhelming majority of women, men and children sold had Christian names. ${ }^{38}$ The process of baptism and assigning names was performed upon the slave's arrival in Portugal. Zurara mentioned that efforts were made to postpone the ceremony until the slave learned at least some Portuguese and could understand the meaning of baptism. Probably, the name of a slave was chosen by the owner and there was a certain fashion involved. In the last two decades of the fifteenth century and the first decade of the sixteenth century, the female name given most often was Catalina, followed by Maria. Amongst male slaves, no name dominates in such a way but most often we find the names Juan, Pedro and Diego. ${ }^{39}$ The range of names given to children born to slaves was wider. Perhaps, the mother-slave's opinion counted in these cases. Amongst the slaves born in Portugal, there is no person with a non-Christian name. However, such names occurred, although rarely, amongst slaves abducted or purchased in Africa and brought to Portugal. Two women - a Moura freed in 1454 , and a black slave woman from Guinea sold in 1472 - kept the Muslim name of Fatima. ${ }^{40}$ It was similar situation with two men: Homar (Omar), freed in 1471, from Guinea and held by his owners "a long time" (muito tempo), and Mahomet, freed in 1493, an older slave of sixty years. ${ }^{41}$ It can be assumed that the practice of keeping a Muslim name existed, but it was rare. In addition, a slave could refuse to be baptised, though in doing so he ruined his chances of manumission. Therefore, Muslim names were only occasionally evidenced at the end of the fifteenth century. In royal documents related to the purchase of clothes for slaves, there appears in 1493 a certain

${ }^{38}$ José Leite de Vasconcelos conducted a study of slave names in Antroponimia Portuguesa. Tratado comparativo da origem, significação, classificação, e vida do conjunto dos nomes proprios, sobrenomes o apelidos usados por nós desde a Idade Média até hoje (Lisbon, 1928), 361-81.

${ }^{39}$ In the volumes 1-3 of PMA, 89 records have been published involving mainly the sale and manumission of slaves which contain their names, including 42 that involved women and girls. Amongst them, 15 had the name Catalina. Amongst the 47 documents involving men and boys, 9 of them had the name Juan, 5 Pedro, and 5 Diego.

${ }^{40}$ PMA, 1/72; 2/122.

${ }^{41}$ PMA, 1/70; 2/61. 
Mafamede - the only one amongst the twelve listed slaves who did not have a Christian name. ${ }^{42}$

A black slave from Guinea named Bukar is mentioned in a document from 1495, and in 1502 a certain Amar was sold, an ethnic Wolof around 30 years of age. ${ }^{43}$ In 1500, according to the notarial records in the Seville town books, the owner of a black tenyear-old boy named Muça transferred the young slave to a jewellery workshop for an apprenticeship. ${ }^{44}$ Since these are Muslim names, these cases perhaps reflect instances when slaves refused baptism.

There were also cases when black slaves maintained their native non-Muslim names. In 1480, a young, black slave woman was sold - about 18 years old, from the Mandingo people - whose name was Banbana. In 1489, a black slave woman was sold - about 30 years old, from the Wolof people - whose name was Penda. ${ }^{45}$ Several other names are doubtful as to their African or non-African origin. A document dated 17 March 1493 shows that King John II still had slaves with pagan names. It cites three of them: Tanbo, Tonbe and Baybry. ${ }^{46}$ But these were, at that time, exceptional cases. There could be various reasons - besides a slave's rejection of baptism - behind a decision to keep a non-Christian name; it might well have been in the interests of the owner. Afonso V, when freeing the Moor woman Fatima in 1454, obligated her to serve in Guinea; perhaps it was preferable in Africa to have a Muslim name instead of a Christian name. Slaves were baptised - or attempts were made to baptise them - from the very beginning, as evidenced by the Zurara text cited above. But, according to the chronicler, 'white Moors' were tougher cases. It is easy to be overwhelmed by possible hypotheses in this regard. In any case, when business and practical issues were involved, the Portuguese turned out to be very flexible.

Common practice consisted of assigning a Christian name during baptism and using that name at least officially. The documents do not allow us to assess to what extent slaves remembered their African names, wanted to keep them or used them in circumstances

42 PMA, 2/57. Zurara indicated cases when baptism was refused; see Zurara/ Soares, 549 .

${ }^{43}$ PMA, 2/116; 3/175.

${ }^{44}$ PMA, $2 / 262$.

${ }^{45}$ PMA, $1 / 119 ; 2 / 4$.

${ }^{46}$ PMA, 2/57. 
beyond the control of their owners. In one document from 1475, a slave appears under two names, Pedro-Muça, a Christian name and a Muslim name. ${ }^{47} \mathrm{He}$ was an interpreter lent out to work in Guinea, which reminds us of Afonso V's decision described above, although we do not know if Fatima had a Christian name.

In most cases, a slave who was baptised and given a new name was thereby brought into Portuguese Christian society. It was both a symbolic and a real change in the life of a slave. Undoubtedly, it exerted an influence on his psyche, though we do not know the degree to which it changed his self-identification; it was probably different in different cases. Baptism and a new name caused a change in how the slave was perceived from the outside. He became a member of the community, though, of course, in the lowest rank of society.

Beyond baptism and the name change, another important way in which a slave assimilated into the Portuguese community was clothing. Slaves came from various regions of Africa. In places influenced by Islam, and where the growing of cotton was developed, it was common to cover the body in a robe, or at least a loincloth. ${ }^{48}$ But in places where cotton was not grown, in the tropical forests, on the coast of Guinea from Sierra Leone to Benin, nudity was common. There, only the minority elite could wear imported cotton clothing. Local clothing and loincloths were made from leaves and plant fibre. During the first Portuguese expeditions to Africa, the explorers viewed nudity critically and very emotionally. ${ }^{49}$ They considered it as a sign of the Africans' civilisational inferiority and as a sign of their savagery.

Seeking to maximise profit, traders shifted the obligation to clothe the slaves onto the buyers. Zurara tells us about this after the previously quoted passage about events in Lagos. After the slaves were partitioned, food was prepared for them and "their bodies were covered with clothing"; those who accepted the garments, learned to like the brightly coloured robes, and some gathered pieces of cloth that fell from the Portuguese robes, and they sewed these colourful

47 PMA, 1/95.

${ }^{48}$ Charles Monteil, 'Le coton chez les Noirs', Bulletin du Comité scientifique et historique de l'Afrique occidentale française, ix (1926), 585-684.

49 Anna Chabrowska, 'Afrykanie w oczach Europejczyków w dobie wczesnej ekspansji kolonialnej. Afryka Zachodnia do końca XV w.' (2008), 21-8 (this is a typescript of a Master's thesis in the archives at the Faculty of History of the University of Warsaw). 
pieces onto their garments and gained great pleasure from this. ${ }^{50}$ Thus, amongst the slaves there was a strong sense of their own aesthetic, and from the moment they found themselves in Portugal, they tried to adapt this aesthetic to the new conditions. This phenomenon was so pronounced that Portuguese observers took notice of it from very early on.

An account of the journey by Silesian knight Nicolas von Popplau to Portugal in 1484 confirms that the obligation to clothe slaves customarily fell to the buyer. Popplau was in Portugal from August to September 1484, in the service of Emperor Frederick III; one purpose of his journey was to gather intelligence. The Silesian knight received two valuable slaves from the king of Portugal. Envoys of the king offered him a choice from 50 slaves who had been "brought in on ships about eight days earlier." They were purchased in Lisbon in the name of the king and in Popplau's presence. "I dressed them immediately," the traveller noted, "because they were completely naked, as God had created them." 51

Evidence regarding the clothing of slaves by owners can also be found in the documents. Five of them, found in the collections of the PMA, contain John II's royal instructions in 1493 to an administrator named Rui Gil, who was to deliver various pieces of clothing to particular slaves working in the royal stables. ${ }^{52}$ The king mentioned the exact types of garments: shirts, pants, caps, various kinds of coats, all of various textiles, including some imported from Bristol, Ypres and France. These were expensive clothes; after all, it involved royal slaves and the ruler's representation. One instruction involves three slaves just imported from the Congo by a certain Pedro. Later, from the year 1510, we have a note sent by the otherwise unknown Maria Pires to an unidentified secretary, in which she recommends the preparation of cotton and linen garments needed "to clothe the blacks" ("para vestir os negros"). ${ }^{53}$ In turn, in 1475, an owner lending

50 Zurara/Soares, $151 \mathrm{f}$.

${ }^{51}$ Reisebeschreibung Niclas von Popplau: Ritter, bürtig von Breßlau, ed. Piotr Radzikowski (Prace Instytutu Historii Wyższej Szkoły Pedagogicznej w Kielcach, 8, Cracow, 1998), 83: “[... die besten zwey Mohren] ... die ohn gefehr vor acht Tagen in Schiffen zugeführet waren. ... Die selben kleidet ich allso bald, denn sie waren ganz nacket wie sie Gott geschaffen hatte."

52 PMA, 2/57, 63, 66, 68, 80.

53 PMA, 5/197. 
a slave-interpreter set a condition, beyond compensation for himself, that if the trade brought good results, then that interpreter would get 50 maravedi for clothes ("a su vestuario"). ${ }^{54}$

Documents of this type are rare; they were usually issued by people who owned many slaves, and who used officials as go-betweens. If the buyer bought one or a couple slaves, he also bought them clothes, without having to document it.

Clothing slaves was as much a spontaneous decision as it was an important method of bringing these people into the Portuguese community. Acculturation occurred, in this case, relatively quickly and effectively, since clothing did not arouse resistance amongst slaves, but rather, was willingly accepted.

Formularies describing slaves at the time of sale or manumission included identifying details that helped slaves preserve their sense of a distinct identity and maintain their connection with the African culture from which they had been uprooted. Such identification thus had an influence contrary to the intended goal, namely acculturation. It is puzzling that documents include details about the slave's place of origin in Africa or ethnic attachment. Such terms as 'natural de ...' (which means 'coming from ...' or 'born in ...') were used. This information was tied to skin colour (escrava negra/escravo negro). In the vast majority of cases, documents relating to individual slaves included information about their origin..$^{55}$ Bulk lists of large transports of slaves included separate headings: origin (origem) and skin (cor) ${ }^{56}$

${ }^{54}$ PMA, 1/95. In the last half of the 15th century and in the 16th century, the maravedi was a small, copper Spanish coin. According to Fernand Braudel (The Mediterranean and the Mediterranean World in the Age of Philip II, 2 vols., 2nd edn [Berkeley and Los Angeles, 1995], i, 420), in the 16th century, 350 maravedi equaled one gold account ducat and 400 maravedi one gold escudo in coin.

${ }^{55}$ E.g., PMA, 1/11, document of Afonso V from 17 May 1454: “... Fatima moura natural de terra 'Arzique' ..."; 1/70, document of Afonso V from 18 Dec. 1471: “... huum escravo de Guinee per nome chamado Homar ..."; $2 / 45$, document from 3 April 1492: “... esclavo de color negro, que a por nombre Juan, natural de Xolofo ..."

${ }^{56}$ E.g., the list of slaves sold in Seville in January, February and March 1496 (PMA, 2/158) contains the following headings: number of slaves, sex, skin, age, origin, seller, buyer, price, transaction fee. On the strong trade connections between Portugal and Seville, and on the similarity of the local situation of slaves in both areas, see below and fn. 72 and 106. See also Ruth Pike, 'Sevillian Society in the Sixteenth Century: Slaves and Freedmen', The Hispanic American Review, xlvii, 3 (1967), 344-59. 
They indicated either a slave's country (or region) of origin, or his tribal attachment - with no distinction made between these types of identification. This information was noted meticulously, which indicates that it was used effectively to identify slaves; perhaps certain places of origin were perceived to provide better quality 'goods'. But the fact is that we do not know how this indicator was used by the owners and buyers, who did not speak the various African languages, which could have helped to identify their slaves' origins. Perhaps, they relied on the statements by traders who were importing the slaves from Africa, or on the information given by the slaves themselves. It is likely that owners recognised different external features of their slaves and thus linked them to their place of origin in Africa. In any case, the determination of place of origin (or ethnicity) must have been useful, since it was commonly noted.

If the original owner or subsequent purchaser recorded, remembered and reiterated his slaves' origins, that information was more easily preserved in the minds of the Africans living in captivity. It was a part of their self-identification. It enabled them to interact with slaves from the same place of origin and even to retain some elements of their own African culture, including not only language, but dancing, singing, music, and various other social gestures. ${ }^{57}$ Of course, amongst the second generation, born in Portugal, identification with African ancestry declined in strength. Nonetheless, such identification could persist in the children through the mother and could be strengthened by the continuous importation to Portugal of slaves originating from the same region of Africa.

Some African slaves were white. They came from the Canary Islands and the Saharan coast of West Africa, inhabited by the Idzagen Berbers (Azenegues). Zurara provided rich information about the capture of the Canarians and the Azenegues, ${ }^{58}$ and while the Azenegues are not mentioned in documents contained in the PMA (notarial records in Seville), the Canarians are mentioned several times. ${ }^{59}$ However, in this group of documents, black slaves are clearly mentioned most often, and while their most frequently recorded place of origin is Guinea, defined rather generally (that is, the Black African coast south of

${ }^{57}$ Saunders, A Social History of Black Slaves, 89.

${ }^{58}$ Zurara/Soares, $93 \mathrm{f.}, 110,121,133 \mathrm{f.}, 139 \mathrm{f}$.

${ }^{59}$ PMA, 1/73 - 1472; 2/158 - 1496; 3/185 - 1503. 
the mouth of the Senegal River), specific information about them shows up in relatively large amounts. Second place (after Guinea) in terms of the number of mentions, is occupied by the Wolof country and people. ${ }^{60}$ Information about slaves from Çapa or Zapa (perhaps Sapis or Sapes from the area around Sierra Leone) is relatively abundant. Less numerous are references to the Mandingos. ${ }^{61}$ One piece of information refers to slaves from Benin, and Mina (Elmina) is also mentioned once. ${ }^{62}$ The fact that Mina is rarely mentioned is not surprising, since until the end of the fifteenth century, slaves were brought from Benin to Mina, but they were not then exported from Mina to Portugal. Individually these names are also mentioned: Alem (which can be understood as 'beyond the sea'), and Gogoli, Cap de Guer, Tymes, some of which are difficult to identify. ${ }^{63}$

All of these names had meaning for people preparing these documents; they were understandable to them and they served as a reference to the geographic and ethnic situation in Africa. These names circulated in Portugal and were carried over to Seville along with the slaves sold there. They were used in the legal process of identifying and assessing the value of the slaves but they also played a role as a medium of information, not only about these slaves, but also about Africa itself. They formed popular imaginary about Africa and its regional divisions, and it was precisely because of the slave trade and the ways slaves were identified that they reached a much larger number of people (than just explorers and traders) from various social groups. They were one of the many carriers of knowledge about Africa, practical and easily digestible. Africa, in all its regional and ethnic diversity, became present in the minds, and in the everyday

${ }^{60}$ PMA, 1/122 - 1480; 2/4 - 1489, 45 - 1492, 53 - 1492, 54 - 1492, 65 - 1493, 69 - 1493, 109 - 1495, 124 - 1495, 224 - 1498; 3/107 - 1501, 171 - 1502, 175 $-1502,211-1503$. These are notarial records from Seville. Wolof territory stretched along the coast from the mouth of the Senegal river to Cape Verde.

${ }^{61}$ PMA, notarial records from Seville: Çapa, Zapa 3/39 - 1500, $79-1501,87$ - 1501, 173 - 1502; Mandingo 1/118 - 1480, 119 - 1480; 2/139 - 1496. The West Mandingos (Mande) inhabited areas of the middle and lower course of the Gambia and the Casamance rivers.

62 PMA, Benin/74 - 1501, King Manuel the Fortunate freed the slave named Lourenço from Benin; PMA, Mina 2/239 - 1499, King Manuel the Fortunate freed the slave named Beatriz for service in Mina.

${ }^{63}$ PMA, notarial records from Seville: 2/61 - 1493, 122 - 1495; 3/57 - 1501, 142 - 1502, 201 - 1503. 
lives, of ordinary Portuguese people and the residents of Seville, who had strong ties to Portugal.

This is all the more true in light of the fact that slaves of both sexes were typically employed as domestic servants. ${ }^{64}$ This had an impact on the subject at hand, namely cultural contact. Male or female slaves serving in their owner's home knew well the owner and his family, their lifestyle and their habits. They often took the name of the owner. ${ }^{65}$ Similarly, the owner knew his servant well, his way of living, his manners. Through contact that was so personal - though it was marked and burdened by the slave's dependency - there existed on both sides a whole range of attitudes, feelings and ways of conducting oneself. We can imagine what it was like, but the sources allow us only to glimpse at a small part of it. In any case, there is no doubt that it was a matter of mutual acquaintanceship.

It worked similarly with regard to other slave activities known to us. If a slave served on the Portuguese caravels sailing to Africa, for example as a interpreter, he also had very close contact with the crew. ${ }^{66}$ He could serve as a deckhand, though usually in such cases it was freedmen who were employed and not slaves. Young slaves - handed over by their owners to craft workshops for an apprenticeship or employed as small street vendors, water carriers and vendors - also had close contact with local Portuguese societies. ${ }^{67}$ However, groups of several dozen slaves employed in establishments such as mills, furnaces and forges, where - because of the specific nature of these workplaces and the labour performed there - they did not have extensive contacts with the local environment, were quite rare. ${ }^{68}$

The unmistakable proximity in which most owners and their slaves lived their lives facilitated the two-way transmission of information. This did not happen in an orderly and thought-out way (as was the case at the court of Infante Henry), but rather in a spontaneous manner, and as a side effect of continuous contact. In any case, one must keep in mind that this contact had a specific nature - it connected master and slave, it was contact between unequal sides. The

${ }^{64}$ Verlinden, L'esclavage, 632; Saunders, A Social History of Black Slaves, 66-9.

65 PMA, 3/64 - 1501, Elvira Rodriguez and her slave Juana Rodriguez.

66 Tymowski, 'How did European Explorers Communicate', 49-50, 52-5.

${ }^{67}$ Saunders, A Social History of Black Slaves, 76-7.

${ }^{68}$ PMA, 2/177 - 1497; 3/92 - 1501. Both documents are quittances for payment for slaves working in the royal mills, approved by King Manuel the Fortunate. 
slave lived under the constant threat of a change in circumstances, including being sold to another owner.

The passage of Zurara's chronicle quoted at the beginning of this article testifies to the pity many felt, and the protests evoked when slaves were partitioned, which was spontaneously perceived as a very cruel act. But as the slave trade developed over time, hearts hardened. The spontaneous - and, in our eyes, commendable - reaction of the common people of Lagos was not repeated. Research into cruelty in human relationships raises numerous problems. ${ }^{69}$ In this research, can we use our contemporary measurements and feelings? Or do we rather need to describe and analyse the value and judgment systems that existed in the past, and thus look for the measure of cruelty typical in the society we are examining here? That is, in a society in which the slave trade became an everyday occurrence that was no longer considered cruel? That having been said, exceptional and pointless abuses were treated as cruel, as shown by the conviction in 1511 of Gonçalo Roiz, a slave ship captain who had thrown living adult and children slaves into the sea. ${ }^{70}$

During the mass transportation of large groups of slaves from Africa to Portugal, people learned of the term peças - the 'pieces' by which people were counted. In lists of slaves transported at the beginning of the sixteenth century, peça meant one adult person, but also a woman with a small child. Thus, in the list of slaves transported in 1506 from Arguin, 6 women with young children were identified as 6 pieces. ${ }^{71}$ This custom became widespread over the course of the sixteenth century and became an expression of the dehumanisation of the human commodity. Tying a female slave to her baby also made practical sense, because it created the possibility of the child's survival, though it limited for some time the woman's ability to work.

Slaves who had just arrived from Africa, as well as those already owned by someone in Portugal, were both subject to sale. A certain number of them were then transported to Castile. This export did not

${ }^{69}$ Janusz Tazbir, Okrucieństwo w nowożytnej Europie (Warsaw, 1993), 7-26.

${ }^{70}$ Monumenta Missionaria Africana, i: Africa Ocidental (1471-1531), ed. António Brásio (Lisbon, 1952), 215-21.

71 'Pieces' in Portuguese lists of slaves transported on ships, see PMA, 3/260 $-1504,262-1505,263-1505$. Mother with infant as 'piece' in the list 5/46 from 1506: "... item seis molheres ... com suas cryanças ... 6 peças ..." 
raise objections, since they were subject to customs fees. ${ }^{72}$ However, sales of slaves to foreigners from countries further afield in the fifteenth century raised concerns and objections. In 1466, the traveller Leo of Rožmital was supposed to obtain two blacks from King Afonso V, but Ferdinand Duke of Viseu successfully prevented this, arguing that the slaves were baptised and could no longer be exchanged. But surely this was not the reason for withholding the gift, since baptised slaves were sold without restrictions. Rather, those who prevented the exchange feared that foreigners would be able to gather intelligence information. According to some informants, Leo instead received two steeds, according to others - two white 'Moor' slaves. ${ }^{73}$ Similarly, the Silesian knight Nicolas von Popplau - mentioned above - was supposed to be presented with "two live blacks" in 1484 by King John II but for unknown reasons he did not receive them. Instead, he was given two slaves purchased at the slave market. The Silesian knight noted that "the country of the Moors, Guinea ... brings to Portugal every year ... a great deal of gold and blacks taken into slavery." When Popplau went to Castile, a customs duty was imposed on these two slaves, which the knight opposed to no avail. ${ }^{74}$ Because he did not mention more about them in his account, Popplau probably sold them in Seville.

The fate of these two slaves: imported from Africa, sold in Portugal to an envoy of the king, given as a present to a foreigner, transported to Castile and sold there again, mirrors the uncertainty and volatility of a slave's life. This was especially true for slaves freshly imported from Africa.

Those who had already long been someone's property were also subject to sale. Amongst the many transactions of this kind, documents regarding the sale of children attract special attention. How these transactions were performed and their circumstances can be a guide to the type of contact owners had with their slaves. According

${ }^{72}$ In PMA, many notarial entries were published from the town books of Seville. The decision of the publishers of PMA to include this material in the collection that concerns the history of Portugal, along with the content of these entries, accentuates the similarities between the situation of slaves in Portugal and that of slaves in Seville. See also below and fn. 106.

${ }^{73}$ Quote from Reisebeschreibung, 74, fn. 311.

${ }^{74}$ Ibidem: "zwey lebendige Möhrin", 78: "Man nennet sonsten der Mohren Landt Ginea. Bringt jährlich sehr viel Goldes und gefangener Mohren aus dem Lande in Portugall"; customs duty: pp. 90, 93. 
to medieval principles, let us accept the age of 12 as the border between childhood and adulthood, in the context, for example, of the possibility of marriage. One must also recall the method by which a slave's age was determined. Only those born in Portugal and then baptised could have an established age. For others, it was written "about", or "more or less."75

Amongst the documents of interest to us from the PMA collection, we find 16 notarial acts from Seville on the sale of children or their transfer to pay off debts. ${ }^{76}$ This is, of course, a limited selection of documents, but it seems to be representative. These 16 documents are from the period 1489 to 1505 . However - given that children were imported from the very beginning of the trade in African slaves (as the fragment quoted above from Zurara's chronicle shows) - the lack of documents prior to 1489 does not mean that children were not brought in before that date. In these documents, the children's ages span from 15 days to 11 years. Children were most often between 5 to 10 years old when sold, which means they could already live without their mothers. Acts of sale of individual female slaves along with children do not seem to suggest that these people were given humanitarian consideration or mercy. Of greatest concern, rather, was the child's survival. We have at our disposal sales documents regarding women with children of a year, year and a half, and two years old. ${ }^{77}$

Ten documents involve also the sale of children alone, without their mothers. They were children either imported from Africa with no mothers, or born in Portugal or Seville by a mother-slave. From the perspective of the fate of these children, both situations were dramatic and similar. However, from the perspective of the relationship between owners and their slaves, there was a difference. Already by 1489 , in the town books of Seville, we find information about the sale of a black slave named Maria, who was from Jaén (Jahen) and was about seven years old and whose buyer came from the same town. ${ }^{78}$ This involved a slave girl born in Europe and all indications are that she was separated from her mother. We also know that free

${ }^{75}$ E.g. PMA, 1/142 - 1483: "de hedad de quarenta anos, poco mas o menos."

${ }^{76}$ PMA, 2/5 - 1489, 6 - 1489, 52 - 1492, 54 - 1494, 70 - 1493, 104 - 1495, 121 - 1495; 3/17 - 1500, 48 - 1501, 139 - 1502, 152 - 1502, $172-1502,202$ - 1503, $224-1504,249-1505 ; 5 / 29-1505$.

77 PMA, 3/152, 224; 5/29.

${ }^{78}$ PMA, $2 / 6$. 
children of this age were sent out into service. But there is also the example of a fifteen-day-old baby sold in Seville in 1492 for the low price of 10 reai in silver. ${ }^{79}$ This striking but isolated incident of a sale without the mother was not motivated by a desire for profit since the owner received only a small amount in return. Perhaps, the child's mother died in childbirth or in puerperium. Or maybe, this was an example of a punishment being meted out to a slave - to which we shall return to below.

Most of the children sold were several years old, already raised by their mother; here, the distinct goal of sale was profit. Some of these children were born in Portugal (or in Castile). One document writes of nine-year-old Magdalena, sold in 1500 in Seville: "nascita en esta dicha cibidad." ${ }^{0}$ In another case, a document speaks directly about the separation of a child from its mother: In 1502, in Seville, the owner sold Catalina, a black slave woman from Guinea who was around 30 years old, and five-year-old Maria, the daughter of one of his other female slaves, Francisca. ${ }^{81}$ Children born in Africa and separated from their mothers there were also sold. In 1492, a seven-year-old boy named Godin, born in the Wolof lands, was sold. The five-year Ysabel, "an esclavita" born in Guinea, was given as a pledge for her owner's debt. ${ }^{82}$

In the light of this material it does not seem that owners felt any inhibition or remorse in selling children and separating them from their mothers. Practical considerations were the deciding factor in the sale of mothers with infants. However, in the sale of older children - it was economic considerations.

We must also keep in mind the kind of source material we have at our disposal, and its limitations. Firstly, many cases in which young slave women were sold might have involved mothers being separated from their children, though this fact was not registered in the documents. Secondly, we do not know the number of cases where the owner did not sell either the woman or her child, and he kept

79 PMA, 2/52. Ten reai in silver make around 340 maravedi - that is, less than one ducat. Since the price of an adult slave (or 'a piece', made up of a mother and her infant) was about 10 ducats, the price of this infant was less than 10 per cent of such an amount. Exceptionally, valuable slaves could cost as much as 30 ducat.

${ }^{80}$ PMA, 3/17. By comparison, the sale in 1500 of 9-year-old Magdalena cost the buyer 7200 maravedi.

${ }^{81}$ PMA, 3/139.

82 PMA, 2/54, 70. Similar information in 2/70, 121; 3/48, 202. 
them both for himself. One indicator could be estate inventories after deceased or bankrupt owners. For example, in 1489, the deceased Pedro Mexia left behind, amongst other things, a 30-year-old black female slave, Ynes, and her six-year-old son with light-coloured skin ("de color loro"). And amongst Luis de la Mezquita's possessions in 1495 were a twenty-five-year-old black female slave, Pendra, and her two sons, each about four years old. ${ }^{83}$ Neither of these owners sold the mother-slave, either alone or with children, though in both cases, the death or bankruptcy of the owner meant that the women and their children ran the risk of separation. In the first case, it is possible that the father of the boy-mulatto was the owner.

Cases of children of black slaves with lighter skin colour were noted several times in our documents. In 1489, a sixteen-year-old slave with light skin colour ("de color loro") named Rodrygo was sold in Seville; he was the son of one Catalina, a black slave belonging to the seller. ${ }^{84}$ Black female slaves could come into sexual contact with white owners under more or less overwhelming pressure, and their rape by owners was also possible. Although they were slaves and because they were Christians, rape was theoretically a forbidden act but in practice it usually went unpunished. There were, however, exceptions. In 1490, King John II pardoned the knight Alvaro de Vila Franca, a resident of Setúbal, married to Violante Afonso. He was accused of having a daughter with one of his slaves, a black Christian from Guinea. With the consent of his wife, he accepted the daughter into his home; that is, he probably legalised her in this way. His wife thus knew about the adultery and the defendant asked for mercy, which he received from the king, provided that this did not happen again. ${ }^{85}$ It can be assumed that the accusation was a form of pressure from his wife and that without her efforts the case would not have been considered. But the fact remains that the knight's act was punishable and slaves were given at least a minimum degree of protection. The wife's consent to bring a child born in such circumstances into their home reminds us that consent could also have been denied; in this case the infant might have been sold. The man could also - for different reasons - decide to sell a baby.

83 PMA, 2/5, 104.

${ }^{84}$ PMA, 2/7.

85 PMA, 2/23. 
Thus, after being clothed and baptised, given a name, taught the language and the rules of work, the gradual inclusion of people brought from Africa into Portuguese society also covered children born to slaves in Portugal. Children inherited the status of a slave, but their place of origin in Portuguese cities or in Castile was noted. Children born in Portugal knew the language better than their mothers, but it was not correct Portuguese; rather it was a simplified and distorted version - fala de Guiné or fala dos pretos and fala dos negros - that is, the speech of Guinea, the speech of blacks. According to historians of Portuguese literature, the first Portuguese work in which an author used this language came as early as 1455 . In the sixteenth century, such works were numerous, and the masterful control of such language and its use in theatre was characterised by the plays of Gil Vicente. ${ }^{86}$ In his comedies, common characters speak in a common dialect, and black slave characters speak fala dos pretos. The use of this language in theatres had a comedic effect and referred to the ordinary experiences of the audience. But through irony it could serve to humiliate and stigmatise the social group that used such speech. It is significant that Afonso Alvares, the sixteenth-century author of comedies and stage dramas, a mulatto by origin, never used fala de Guiné ${ }^{87}$ Perhaps, it would have been too painful for him. There were a few black slaves who used correct Portuguese, and they were defined through the use of a distinct term - ladinhos ${ }^{88}$ - which also emphasised their exceptional situation. Along with skin colour, language was thus one of the durable features distinguishing slaves from other members of society. Both features were more durable than the slaves' legal status, since that could be abolished through manumission.

Manumission usually came as the result of a decision made by the owner. In some cases, however, a slave was entitled to manumission by law. A slave-interpreter who - during expeditions to Africa - obtained four slaves for his master was supposed to be freed. Alvise Cadamosto described this system in his account of his travels in 1455 and 1456. But the oldest document on the manumission of an interpreter in the

${ }^{86}$ Teyssier, La langue; Russell, 'Some Socio-Linguistic'; Saunders, A Social History of Black Slaves, 99-101, 203, fn. 66; Janina Klave, Historia literatury portugalskiej (Wrocław, 1985), 120-2.

${ }^{87}$ Saunders, A Social History of Black Slaves, 101; Klave, Historia literatury, 125.

88 Saunders, A Social History of Black Slaves, 101. 
PMA comes from the year $1475 .{ }^{89}$ In 1477 , João Garrido was freed; he was a black slave born in Guinea and owned by the merchant Gonçalo Toscano, a resident of Lagos. This same João Garrido was baptised and repeatedly travelled as an interpreter to the lands of Guinea. $\mathrm{He}$ could have become 'a Moor' and lived again as 'a Moor' ("viiver como mouro"), but he always returned to his master and to the Kingdom of Portugal. Thus - according to the document - he was a good and faithful servant. For these reasons, a royal official, by force of royal law and in the name of John II, recognised this slave as "liberated and free ... with the right to live and work in the Kingdom as any other Portuguese Christian." 90

Services provided by slaves during expeditions to Africa were one of the most important reasons for their manumission. In 1499, King Manuel the Fortunate freed his slave Beatriz Gomez precisely for the services she provided during her stay in São Jorge da Mina Castle (Elmina).${ }^{91}$ In 1510, Manuel de Gois addressed a letter to the king asking for his consent to free a slave named Fernão de Ávila, who had been sent to the Kingdom of Benin as an interpreter working alongside a Portuguese agent. Fernão remained in Benin for three years working on behalf of Portugal. ${ }^{92}$ Sometimes, the king freed a slave on the condition that he provide services in Guinea. The first known document of this type comes from 1454, that is, of course, very early on. In this case, King Afonso V freed Fatima, mentioned above, a female Moor from terra de Arzique. ${ }^{93}$

A frequently cited reason for manumission was the slave's sincere religious faith. In a different context, we quoted the example of Pero Negro, who fled to Morocco, but then returned because he felt himself to be a Christian. The manumission of the interpreter João Garrido was justified as much by the sincerity of his faith as by his services in Guinea. In 1492, King John II freed the slave Catarina, who had

${ }^{89}$ Cadamosto/Leporace, 77-8; an act of manumission from 1475, see PMA, 1/95. See also Tymowski, 'How did European Explorers Communicate', 54-5.

${ }^{90}$ PMA, 1/101: "Porem mandamos ... que ajam o dicto Johão Garrido por forro e liure viindo elle a estes Regnos e o leixem em elles morar trautar como qualquer outro cristãao portuguees ..." The same document can be found in Descobrimentos portugueses, ed. João M. da Silva Marques, iii: 1461-1500 (Lisbon, 1971), no. 132, pp. 173-4.

91 PMA, 2/239.

92 PMA, 5/180.

93 PMA, 1/11. 
been brought from Guinea by the merchant Bartolomeo Marchionni when she was eight years old and sold to a Jewish merchant from Lisbon named Guedelha Guoaliter. After two years, Catarina was baptised in the Church of Saint Mary Magdalene and served Bartolomeo Marchionni as a free person. A court case arose between the two merchants. The King settled the dispute by freeing Catarina. The justification was her faith. ${ }^{94}$ This event provides evidence of the antiJewish sentiments and actions in Portugal at the end of the fifteenth century - that is, in the period when Jews who did not convert to Christianity were being expelled from the kingdom. Although the ban on Jews and Muslims owning slave-Christians already existed, the law was only truly enforced at the end of the century. ${ }^{95}$

Manumission could also be an expression of the religious devotion of the owner and his desire to perform an act pleasing to God. In Seville's notarial register under the date 13 February 1503, there is a record documenting the manumission by a monk, Lope Mexia, of a certain black slave woman named Catalina, 14 years old, "por memoria de la pasyon de nuestro Señor Jesu Christo" - and, it adds, "e por servicios." This same monk on the same day freed a fourteenyear-old Canarian named Pedro on the condition that for five years he would serve a certain Teresa Mexia, probably from the same family as the monk. This was thus a manumission secured by a hard and long obligation. Eight days after those manumissions, on 21 February 1503 , the same benefactor, defined specifically as "frey Lope Mexia, comendador de la orden de Sancti Spiritus", freed a black woman from Guinea named Catalina, also 14 years old, because this slave "es cristiana como por los muytos, buenos y leales servicios que le ha fecho ..." ${ }^{96}$ Another slave, also named Catalina but 40 years old, was released in 1494 because - according to her owner - "she served me for many years ... and performed many good and loyal services every day ... to my satisfaction and gratitude." ${ }^{97}$ Similar wording is found in a document from 1495 regarding the services of a 40-year-old slave named Elena. In 1497, the manumission of Catalina was documented, a 30-year-old slave, "por servicios e porque es christiana." 98

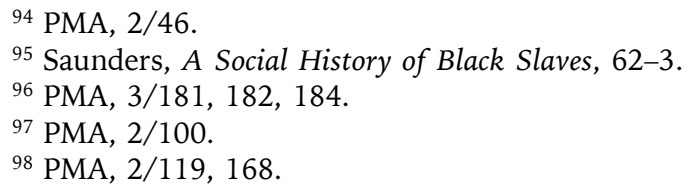


Sometimes, the mention of faithful service covers a more complex, even cruel reality. In 1493, Mahomed - a black slave who was about 60 years old - was freed..$^{99}$ He kept his Muslim name and thus the Muslim faith which, in this case, did not prevent manumission. He was praised for his services. But manumission at such an advanced age was more like abandonment. After all, it freed the owner from the obligations and benefits owed by him to a slave.

Thus, the three main reasons given in the documents for manumission are the slave's sincere Christian faith, good service, and exceptional merits. One can, of course, assume that these items of information were the product of a standard form, but - no matter how schematic - they reflected the intentions of the master. In any case, some of the documents are full of comprehensive and detailed descriptions of the actions and achievements of slaves. The fourth reason for manumission, silent in the texts, was to get rid of an old or sick person.

It was also possible for a slave to be freed under the obligation of continued service, or he could buy his own freedom. In 1504, Pedro Pinelo, a canon of the Cathedral of Seville, transferred to a certain Diego Osorio his rights over the slave Leonor and her two daughters - Luzia and Andrea. Leonor obligated herself and her daughters to serve the canon and pay him, in exchange for manumission, the sum of 11,000 maravedi. ${ }^{100}$

An exceptional act of manumission also comes from Seville in 1501. Here, Elvira Rodriguez, a free black woman and resident of Seville, entered her testament into the town book. She commended her soul to God and to the Virgin Mary, and wanted to be buried in the Church of St John. Then, she stated that she would free Juana Rodriguez, her black female slave who was 20 years old, "porque es christiana e por servicios que le ha fecho ..." This passage in the entry, sounding quite formulaic, was complemented by a very personal declaration: Elvira made the liberated Juana her heir "por servicios que le ha fecho e amor que le tyene ..."101

In acts of manumission, certain wording is repeated (probably entered according to the formulary) that refers to the freedoms and rights due to those liberated: to reside, to travel, to undertake various

${ }^{99}$ PMA, 2/61. Saunders cites other examples of manumission as the abandonment of an old or sick slave in A Social History of Black Slaves, 141.

100 PMA, 3/223.

101 PMA, 3/64. 
activities. This was most clearly expressed in a passage quoted above from a document from the year 1477 - the freedman could live in the kingdom "as any other Portuguese Christian."

In 1490, King John II issued a document regarding Isabel Anes, the widow of Fernão Rebelo, a black resident of Lisbon. The king granted her the privileges due to widows of those who served in Guinea. The document uses the words "aas veuvas molheres de nossos vasallos."102 Rebelo thus had all the rights of a free person; he was described as a vassal of the king, and he married a Portuguese woman, all of which illustrates his integration into the local society.

Evidence for such an interpretation is also provided by employment contracts for black freedmen as soldiers. In 1500, in Seville, a black man, Anton Mexia from the St Lawrence parish, served as lanceiro for the pay of 34 maravedi a day. In the same year, the black man Andrés Mexia, a resident of Seville's St Vincent parish, entered into an agreement to serve as a crossbowman (ballestero) for 35 maravedi a day. ${ }^{103}$ In 1501, Juan López, a black resident of Seville's St Vincent parish, and Esteban Marfin - an agricultural worker (lavrador) - together contracted a loan for 970 maravedi from Pedro de Niebla, who was also a resident of Seville, in the parish of Santa Maria. ${ }^{104}$ Probably in agreement with the formulary, entries defining a freeman, regardless of skin colour, contain information about the place of residence ("visinho de ...") and parish ("en la colacion de ..."). These mentions from documents indicate the integration of black freedmen in the urban community of Seville.

Another type of entry in the town books were authorisations granted by free black people of African descent to representatives chosen by them. ${ }^{105}$ The question arises whether the situation in Portugal was similar to the situation reflected in documents from Castile, and above all Seville. Evidence could be provided by an entry in the town books from 1502. Here, Bartolomé de Pinos, a carpenter from Seville, empowered a black sailor and resident of Lisbon, João Gonçalves, to collect all the debts owed to the carpenter by Portuguese ship owners and builders for work done on the ships sailing to Guinea. ${ }^{106}$

\footnotetext{
102 PMA, 2/20.

103 PMA, 3/8, 14.

104 PMA, 3/62.

105 PMA, 3/111 - 1495, 112 - 1495.

106 PMA, 3/177.
} 
The documents cited here show the variety of issues and activities involving free black residents of Seville and Lisbon. They had the right to appear before courts and city offices, to borrow money, to represent other people or to give and receive authorisation. Amongst them were sailors, soldiers, agricultural workers, artisans and interpreters. They worked and lived in Seville and Lisbon. As members of caravel crews, they travelled to Guinea. They all were - and this was obvious to their contemporaries - Christians. In the documents, their names were given (sometimes their surnames), skin colour, city, neighbourhood, and the parish to which they belonged. In contrast to entries involving slaves, never once was their place of origin in Africa entered. After all, the place of origin of free blacks was the city in which they lived and worked and where the laws covered them.

Judging from the conduct of the free black Portuguese and Castilians who went to Guinea and returned to Portugal and Castile, we can conclude that they accepted their fate. They adopted the religion, language (whether in the form of fala dos pretos or pure Portuguese) and customs; they learned various skills and professions; and they could marry. But one must clearly keep in mind that only a clearly small minority of slaves was ever freed. The documents do not allow us to investigate what parts of, and to what extent, African customs and culture were maintained by these people. This is all the more true when it comes to the majority who remained in captivity until the end of their lives. We can presume that the degree to which they assimilated, and the degree to which they accepted of the fundamental change in their fate, and above all slavery itself, was much less than in the case of freedmen.

The principal change, alongside slavery, in the lives of Africans imported to Portugal came when they were deprived of their family and close relatives. Africans must have felt this loss acutely, especially since their culture was characterised by the specific role played by the extended family and clan ties. Africans lived surrounded by a great number of people who were close to them. Suddenly, in Portugal, they were lonely. Young women did in fact bear children, but they lived near the owner's family, which was alien to them, and in constant fear of separation from their offspring. The fact that black Africans placed a great deal of importance on searching for loved ones is eloquently reflected in Elvira Rodriguez's testament, quoted above, when - liberating her slave - she added: "por ... amor que le tyene". 
The longing for one's homeland and relatives must have weakened over the years as slaves gradually came to terms with their fate as people reduced to slavery. In most cases, assimilation was inevitable. However, a fragment of a description of Northwest Africa by Valentim Fernandes is thought-provoking. Writing about the Azenegues - Berber fishermen from the Atlantic coast, their customs and their poverty, about their abduction by the Portuguese in the 1440s, Fernandes added:

I knew, for example, a certain Azenegue captured as a child and raised in Portugal, where he lived as a Christian for 24 years. Then, he ran away and returned to his land, where he lives now - deprived of everything, naked, as poor as the others, maybe even poorer, because he is not able to do anything. He lives on alms given to him by others [Azenegues]. He could live better, have good clothes, but his nature did not allow him this. ${ }^{107}$

The nature of intercultural contact as it occurred in Portugal in the late Middle Ages and early modern era, due to the importation of African slaves, was determined by several factors: the relatively small number of slaves (reaching, however, up to 10 per cent of the population in some cities), the coercion involved in maintaining the intercultural contact that affected slaves (and, to a large degree, freedmen), the lack of alternatives to this contact, the position of slaves on the lowest rung of society, and - last but not least - the uniformity of Portuguese culture compared to the diversity of African cultures (and languages).

Portuguese sources reflect a deep conviction in the superiority of Christian culture and a determination that slaves brought from Africa needed to be baptised and induced into accepting a European lifestyle. The material collected here indicates that this objective was largely achieved, at least when it comes to the external manifestations of assimilation. This conduct and thinking also characterised the residents of Seville and those parts of Castile that remained in close commercial relationship with Portugal. In the texts, however, there

107 Valentim Fernandes, Description de la Côte d'Afrique de Ceuta au Sénégal (1506-1507), ed. Pierre de Cenival and Théodor Monod (Paris, 1938), 122: “... conheçi huum Azenegue que foy tornado em pequeno e criado e christão em Portugal 24 annos, e fugio e foy ter a sua terra e viue assi desnudo e desauenturado pobre e muyto mais que os outros, porque non sabe trabalhar e viue de esmolla dos outros onde bem podera viuer melhor e ter booms vestidos, porem a naturaleza ho non leixou." 
is no direct mention of the reverse effects of contact - that is, the transformation of Portuguese culture. Probably, until the beginning of the sixteenth century, most of the Portuguese did not think about or perceive this phenomenon. It was significantly weaker than the assimilation and acculturation of black Africans.

For the Portuguese, life in their own kingdom with a relatively large group of Africans, mainly concentrated in the towns, was a matter of everyday existence. A great deal was known about these Africans. Certain information was widely circulated, including the place in Africa from which a slave had come. People were able to distinguish amongst black Africans based on their place of origin. Despite baptism, African names remained in use in some cases. Sexual contact, voluntary or forced, brought about the emergence of a group of mulattos. The language used by Africans was a simplified form of Portuguese. Its use gave rise to ridicule and irony, as reflected in the literature of the time. Beyond skin colour and slavery itself, language was one element that marked the human, relegating him to a low status in society. At the same time, Christianity functioned as a force for the integration of black slaves into society.

trans. Alex Shannon 